ELORE (ISSN 1456-3010), vol. 20 - 1/2013.

Julkaisija: Suomen Kansantietouden Tutkijain Seura ry.

[http://www.elore.fi/arkisto/1_13/kaarlenkaski_saarinen.pdf]

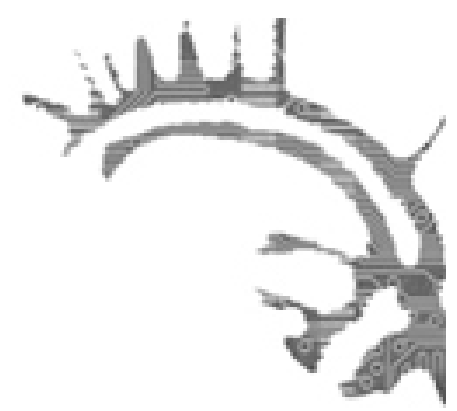

KATSAUS

\title{
MANSIKKI VAI NUMEROSARJA? LEHMIEN NIMEÄMISEN MERKITYKSET JA MUUTOKSET
}

\author{
Taija Kaarlenkaski ja Kati Saarinen
}

Ihmisoikeuksiin katsotaan kuuluvan muun muassa oikeus omaan nimeen ja kansalaisuuteen. Oma nimi yhdistetään yksilöllisyyteen ja tunnistettavuuteen. Nimeä arvostetaan, ja vastaavasti maineen menettämistä ja ikävien asioiden liittämistä omaan nimeen pidetään häpeällisenä asiana. Mielikuva nimettömästä ihmisestä tuntuu lohduttomalta, ja nimenanto lapselle lienee jollakin tavalla ritualisoitu lähes kaikissa kulttuureissa. Myös ihmistä lähellä oleville lemmikki- ja kotieläimille on jo vuosisatojen, ellei -tuhansien ajan ollut tapana antaa yksilöllinen erisnimi. Näin on myös nautojen kohdalla.

Vaikka naudan asema on kuluneiden reilun viidenkymmenen vuoden aikana muuttunut kotieläimestä tuotantoeläimeksi ja karjakoot ovat kasvaneet voimakkaasti, ainakin lypsylehmille on edelleen tapana antaa oma nimi. Tuotantoeläimen asemasta huolimatta karjanhoitajat pitävät nautoja usein yksilöinä ja kiinnittävät huomiota niiden erilaisiin luonteenpiirteisiin (esim. Holloway 2001, 301; Falkengren 2005, 217-218; Wilkie 2010; Kaarlenkaski 2012). Nimen antaminen korostaa eläimen käsittämistä omana persoonanaan ja erottaa sen muista samaan lajiin kuuluvista. Nimeäminen tuo eläimen lähemmäksi ihmistä ja korostaa sen erityistä asemaa. (Leibring 2000, 17-18; Tervo 2004, 113-114; Kalske 2005, 13; Borkfelt 2011, 121-122.) Nimetyllä eläimellä on oma elämäntarinansa ja ajallinen sekä paikallinen sijaintinsa. Tähän liittyy myös se, että nimettyyn eläimeen todennäköisesti kiintyy helpommin kuin nimeämättömään. (Phillips 1994, 121, 132; Melson 2001, 68-69; Ellis \& Irvine 2010, 29.) 
Taija Kaarlenkaski ja Kati Saarinen: Mansikki vai numerosarja?

Tässä katsauksessa tarkastelemme lehmien nimeämistä ja siihen liittyviä merkityksiä lähtökohtana erilaiset nautoihin liittyvät tutkimukset ja aineistot. Kotieläinten nimistöä on jonkin verran tarkasteltu kielitieteelliseltä kannalta (esim. Leibring 2000; Kalske 2005), mutta kirjoituksessamme lähestymme nautojen nimeämistä yhteiskunnallisesta ja kulttuurisesta näkökulmasta. Kysymme, mitä merkityksiä kotieläinten nimet saavat kirjoitetuissa lehmäaiheisissa kertomuksissa ja karjanhoitajien puheissa. Mitä nimen antaminen tuotantoeläimelle merkitsee, ja mitä se kertoo ihmisen ja eläimen välisestä suhteesta? Onko ihmisen helpompi kiintyä eläimeen, jos sille on annettu tietyin perustein nimi? Onko nimen antaminen edellytys eläimen yksilölliselle kohtelulle?

Taija Kaarlenkaski tarkastelee Suomalaisen Kirjallisuuden Seuran ja Maaseudun Sivistysliiton vuonna 2004 järjestämään kirjoituskilpailuun Ei auta sano nauta lähetettyjä lehmäaiheisia kertomuksia. Kirjoituskilpailu oli erittäin suosittu: se sai runsaasti huomiota mediassa ja siihen lähetettiin lähes 3000 kirjoitusta. Kilpailun kirjoitusohjeet olivat värsin väljät. Esitteen mukaan kilpailussa koottiin "lehmiin liittyviä muistoja, kokemuksia ja tarinoita", ja siihen sai osallistua tosipohjaisin muistelukertomuksin tai kaunokirjallisin tekstein. Muistelusarjaan kirjoittamisen virikkeeksi tarjottiin erilaisia näkökulmia emännästä kaupunkilaisserkkuun, ja kaunokirjalliseen sarjaan kehotettiin kirjoittamaan lehmään liittyvä novelleja ja tarinoita. Ajallisesta perspektiivistä tarkasteltuna kirjoitukset painottuvat menneisyyteen, mutta joukossa on myös 2000-luvulle sijoittuvia kertomuksia. (Kaarlenkaski 2012.) Vaikka nimiteemaa ei mainittu lainkaan kirjoitusohjeissa, nautojen nimet olivat aineistossa hyvin yleinen kerronnan aihe. Suuri osa kirjoittajista vähintäänkin mainitsi tekstissään joitakin lehmien nimiä.

Kati Saarinen tuo esille millaisia merkityksiä lehmän nimeämisellä on nykyisille lypsykarjan hoitajille. Tätä tarkastellaan haastattelu- ja kyselyaineistojen valossa. Haastatteluaineistot on kerätty vuosien 2006-2008 aikana. Saarisen pro gradu -tutkielman, "Onkohan tää homma näille lehmille miten tuskallista?" Maidontuottajien ja asiantuntijoiden määritelmiä eläinten hyvinvoinnista ja tiedon luotettavuudesta (2007), aineisto perustuu Etelä-Karjalan alueella tehtyihin maidontuottajien haastatteluihin vuonna 2006. ELKÄ-projektin (Eläinlähtöinen käsittely - kuinka käsitellä nautaa lajin käyttäytymispiirteet ja hoitajan työturvallisuus huomioiden) haastattelut on toteutettu vuonna 2008 (Saarinen \& Raussi 2009). Maitotilan hyvä vointi -tutkimushankkeen kyselyaineisto perustuu maidontuottajille vuonna 2010 lähetettyyn kyselytutkimukseen. Kyselylomake lähetettiin 400 satunnaisesti valitulle suomalaiselle maitotilalle. Analyysikelpoisia vastauslomakkeita saatiin 47 prosentilta tiloista. Aineistossa parsinavetoita oli $72 \%$ ja pihattoja $21 \%$. Vastanneiden mediaani-ikä oli 50 vuotta, naisia heistä oli $44 \%$. Nautojen hyvinvointia mitattiin eläinten hyvinvointi-indeksillä (EHV). Indeksi muodostettiin 40:stä nautojen hyvinvointiin liittyvästä kysymyksestä, joista 10 oli valintakysymyksiä ja 30 väittämiä. Kysymyksissä huomioitiin Welfare Quality ${ }^{\circ}$-menetelmän ${ }^{1}$ kriteereitä ja periaatteita lomakekyselyyn soveltuvin osin. Lisäksi kysyttiin tuottajan eläinsuhteesta. EHV-indeksin valintakysymykset ja väittämät painotettiin sen mukaan, miten niiden tutkimusten perusteella tiedettiin edistävän tai heikentävän nautojen hyvinvointia. Mitä suurempi EHV-indeksi oli, sitä paremmaksi nautojen hyvinvointi tilalla tulkittiin. EHVindeksin kysymyksiin sisältyi myös kysymys siitä, kuinka tärkeänä vastaaja pitää sitä, että tunnistaa kaikki lehmät nimeltä. Tuloksia tarkasteltiin regressiomallilla. (Kymäläinen 
Taija Kaarlenkaski ja Kati Saarinen: Mansikki vai numerosarja?

2011.) Maitotilan hyvä vointi -hankkeessa haastateltiin maidontuottajia Etelä- ja PohjoisPohjanmaalla tilakäyntien yhteydessä, jossa myös tarkasteltiin navettojen olosuhteita ja havainnoitiin eläimiä. (Kymäläinen 2011).

\section{NAUTOJEN NIMEÄMISEN HISTORIAA}

Karjanhoito elinkeinona levisi Suomen alueelle viimeistään rautakaudella, ja samoihin aikoihin sana nauta tuli suomen kieleen, todennäköisesti germaaniselta kielialueelta. Sanan etymologia viittaa omaisuuteen, josta nautitaan. ${ }^{2}$ Omaperäisten karjan nimitysten, kuten lehmä, vasikka, hieho, mullikka, sonni ja härkä, otaksutaan olevan vanhempia kantasuomalaisia sanoja. (Vilkuna 1976, 19, 24; Häkkinen 2002, 34-35.) Vaikka nykyisin arkisessa kielenkäytössä nautaa ja lehmää pidetään lähes synonyymeina, varsinaisesti sana lehmä viittaa vain aikuiseen, poikineeseen naarasnautaan. Sonni taas on urosnauta ja härkä kuohittu uros. Vasikka on poikanen, mulli nuori uros ja hieho nuori naaras, joka ei ole vielä poikinut. Kotieläinten merkityksestä kertoo se, että saman lajin eri-ikäisille ja eri sukupuolta edustaville yksilöille annettiin omia nimityksiään, mikäli ne olivat tavoiltaan tai käyttöarvoltaan erilaisia (Häkkinen 2002, 40).

Varhaisimmista suomalaisista nautojen erisnimistä ei ole säilynyt tietoja, mutta lehmiä on nimetty jo ainakin suomalais-virolaisella yhteisajalla, sillä suomen ja viron kielissä on useita yhteisiä lehmännimiä. Vanhimmiksi nimiksi on arveltu -kki-loppuisia nimiä, kuten Mansikki, Mustikki tai Punikki. Kustaa Vilkuna on ehdottanut, että nimikkovasikka olisi voinut saada nimen omistajaltaan, esimerkiksi Airi: Airikki, Anni: Annikki ja Lempi: Lemmikki. Lisäksi nimeämisen lähtökohtana on käytetty esimerkiksi eläimen ulkonäköä, kuten väriä, sekä erilaisia luonnosta otettuja nimityksiä, kuten kasvien nimiä. (Ojansuu 1912, 9-27; Vilkuna 1976, 22.) Suomen Kansan Vanhat Runot-kokoelmasta löytyvät muun muassa Mansikki, Hermikki, Kirjo, Karjo, Perjo, Lemmikki, Muurikki, Heluna, Haluna, Paurikki, Punikki, Perjakka ja Viikuna. Ihmisten nimiä, kuten Aili, Bertta, Kaisa ja Maija, käytettiin ainakin jo 1900-luvun alussa. Tuolloin kotieläinten nimistä kirjoittanut Heikki Ojansuu arveli tällaisen nimenantotavan olleen varsin uusi ja "syntynyt uuden ajan eläinystävällisten virtausten mukana sekä siitä syystä, että vanhat nimenantotavat ovat unohtuneet tai karjan suuresti lisääntyessä osoittautuneet riittämättömiksi." (Ojansuu 1912,9-10.)

Ennen karjantarkkailun yleistymistä lehmien nimeäminen oli varsin vapaata. Jossain saatettiin noudattaa tapaa johtaa vasikan nimi emän nimestä hieman muuttamalla tai antaa vasikalle samalla kirjaimella alkava nimi kuin emällään. Vuonna 1957 tarkkailukarjoja varten annettiin suositus, jonka mukaan samana vuonna syntyneille vasikoille pitäisi antaa samalla kirjaimella alkava nimi. Suositusta on myös noudatettu hyvin uskollisesti. Sinänsä karjantarkkailu ei edes vaadi lehmien nimeämistä, vaan tietojärjestelmissä eläimet erotetaan numerosarjan perusteella. Vuosina 1974-1990 suosituimmat lehmännimet olivat Ystävä, Kielo, Yrtti, Omena ja Ruusu. (Ojansuu 1912, 12-13; Vatanen 1997, 6, 22-24, 29.) 
Taija Kaarlenkaski ja Kati Saarinen: Mansikki vai numerosarja?

\section{LEHMIEN NIMET KIRJOITETUSSA KERRONNASSA}

Ei auta sano nauta -kirjoituskilpailuaineiston kirjoituksissa lehmien nimet ovat keskeinen osa niihin kytkeytyviä merkityksiä. Lisäksi useat kertojat mainitsevat, että lehmäkin oppii tuntemaan nimensä. Monet muistavat lapsuuden lehmät nimeltä vielä vuosikymmenien jälkeen. Näin muistelee 69-vuotias mies 1940-luvulle sijoittuvan lapsuutensa lehmiä:

[M]eillä oli Muisto ja Lilja. Kumpikin oli nupopäitä. Muistolla oli tummanruskeat kylet ja selässä kapea kaista valkoista. Lilja oli lähes valkoinen kokonaan, vain kylessä oli vähän punaruskeaa. Muisto ja Lilja poikivat kumpikin neljätoista tai viisitoista kertaa. Yleensä kotonani pidettiin neljää lehmää, harvoin viittä, sekä vasikat, lampaat ja hevonen. Myöhemmin meillä oli Omena, Kyittö, Kirjo, Heluna ja Mansikki. Omena oli kokonaan valkoinen ja sarvipää. Kyittö oli kylistään tummanruskea, nupopää ja kesyluonteinen. Kirjossa oli aika paljon valkoista, kylet olivat vaalean ruskeat ja kirjavat nimensä mukaan. Kirjo oli hyvin kevytliikenteinen ja nupopää. Heluna oli myös punaruskea, aika kookas lehmä. Yritti usein olla määräävä lehmä kokonsakkin takia. Mansikki nimi annettiin aika paljon kuvioitten ja värin perusteella. Mansikilla oli kylissä ja otassa mansikan muotoisia punavaltaisia kuvioita. Mansikki ei koskaan saanut johtajalehmän valtaa vaikka olikin hyvin ketterä liikenteinen.

Jossain välissä oli myös Punikki niminen lehmä. Punikki oli kokonaan vaaleanpunainen nupopää. Isä ei tykänny Punikki nimestä koska se muistutti liikaa 1918 vuoden kapina-ajasta.

(SKS. KRA. EASN. Nimim. Pieni Paimenpoika; mies 69 v.) $)^{3}$

Tekstin lehmät nimettiin pääasiassa ulkonäöllisten piirteiden mukaan. Näin on saanut nimensä myös Mansikki, josta on muodostunut stereotyyppisin suomalainen lehmännimi, suorastaan lehmän synonyymi. Katkelman loppuosan kuvauksessa Punikki-lehmästä tulee esille, että kotieläinten nimiin liittyvät assosiaatiot saattoivat olla myös poliittisia. Edellä mainittujen Liljan ja Omenan lisäksi kasveihin ja luontoon liittyvät nimet ovat kirjoituksissa muutenkin yleisiä; muun muassa Asteri, Esikko, Lemmikki, Kielo, Oliivi, Puolukka, Oksa, Kukka ja Ulpu mainitaan. Tärkeimmillä - tai persoonallisimmilla lehmillä saattoi olla virallisen nimen lisäksi vielä lempinimi.

Lehmien puhutteleminen nimien sijasta numeroilla mainitaan yhdessä, todennäköisesti 1970-luvulle sijoittuvassa kirjoituksessa. Kyseisellä tilalla lehmiä tosin oli vain kahdeksan, joten parsipaikkojen mukaan annettuja numeroita käytettiin lähinnä nimen tapaan. (SKS. KRA. EASN. Nimim. Juski; mies 38 v.) Lehmien nimeämisessä kerrotaan olevan monenlaisia käytäntöjä. Eräs kirjoittaja kertoo, että heillä ei anneta lehmille ihmisten nimiä, mutta kaiken kaikkiaan naisten etunimet lehmien niminä ovat aineistossa varsin tavallisia (ks. myös Leibring 2000, 427-430). Esimerkiksi Ilona, Emma, Jonna, Natalia, Santra Lovviisa, Esteri, Sofia, Siiri, Roosa, Tuulikki ja Annikki on mainittu teksteissä. Onpa mukana yksi miehisen nimen saanut Onni-lehmäkin. 
Taija Kaarlenkaski ja Kati Saarinen: Mansikki vai numerosarja?

Inspiraatiota on saatu myös julkisuuden henkilöistä ja tv-ohjelmien henkilöhahmoista. Mainitaan esimerkiksi 1980-luvulla suositun amerikkalaisen tv-sarjan Dallasin innoittamat Pamela ja sen vasikka Sue-Ellen, lehmätaiteestaan tunnetun taiteilijan mukaan nimetty Äkkijyrkkä sekä laulaja Maija Vilkkumaan kaima Vilikkumaa. Vasikoita kerrotaan nimettävän esimerkiksi syntymähetken säätilan mukaan: Usva, Pouta, Pilvi, Sarastus, Räntäsade. Eräs kertoja mainitsee vasikan saaneen nimeksi Vemmelsääri pitkien säärten ja suurten korvien perusteella.

Nimeltä mainittuja sonneja on kirjoituskilpailuaineistossa varsin vähän, vaikka jokunen kirjoittaja kertoo myös sonnivasikoiden nimeämisestä. Nimien vähäisyys johtunee siitä, että sonnit eivät ole karjassa yhtä pitkään kuin lehmät ja niiden vaihtuvuus voi olla nopeaa (ks. myös Leibring 2000, 28-29). Teksteissä esiintyviä sonnien tai sonnivasikoiden nimiä ovat esimerkiksi Jooseppi, Teemu, Rane, Reigani, Elvis, Mersu, Mosse, Nuppo ja Toope. Nimeämisen lähtökohdat ovat siis samantapaisia kuin lehmilläkin. Siitossonnit taas on jo yli sadan vuoden ajan nimetty karjatilan mukaan, kuten aineistossa mainitut Monikkalan Galiffi ja Ylikorven Hamari (ks. Tervo 2004, 115).

Perinteisten ja yleisten lehmännimien, kuten Mansikki, Omena, Heluna ja Ystävä lisäksi kirjoituskilpailuaineistosta löytyy myös erikoisempia nimiä, kuten Rihmarulla ja Rököpuola, Tuskanen sekä Kananmunapää, joka sekin on saanut nimensä ulkomuodon perusteella: "Sillä on sellainen munan muotoinen pää ja aivan vitivalkoinen, eikä ole sarvia ollenkaan" (SKS. KRA. EASN. Nimim. Uneksija; nainen 38 v.). Vaikutteita nimeämiseen voidaan lisäksi saada kaikenlaisista ympäröivistä ilmiöistä:

Vasikan syntymän aikoihin nähdyt tv-ohjelmat, urheilukilpailut ja politiikan tapahtumat ovat nimenneet mm. Orrekurren, Kahjokatin, Etykin, Mitaliminnin ja Ladylakun. Taannoinen missi nimesi Lolan ja Odun. Göteborgin MM - kisojen aikaan syntynyt Jojo meinasi saada nimekseen Jöötteporin, mutta huomasivatpa sen näyttävän kirjoitettuna melko hassulta.

(SKS. KRA. EASN. Nimim. Meni; nainen 35 v.)

Verrattuna tietoihin 1900-luvun alusta lehmien nimet ovat monipuolistuneet. Niminä käytetään sekä "valmiita", totuttuja lehmien nimiä että uusia itse keksittyjä (ks. Leibring 2000, 26-28). Nimikirjon laajentumiseen on luonnollisesti vaikuttanut se, että nimettäviä eläimiäkin on tiloilla enemmän. Lisäksi alkukirjainsääntö saattaa vaatia mielikuvituksen käyttöä nimeämisessä. Kuten esimerkeistä käy ilmi, nimissä on usein mukana myös huumoria.

Nimen antamista lehmälle pidetään siis tärkeänä nykyisinkin, ja nimeämisen voi nähdä eräänlaisena merkkinä eläinten yksilöllisestä huomioonottamisesta ja hyvästä hoidosta. ${ }^{4}$

Paljon parjattu EU ei ole vielä vaikuttanut meidän navetta-askareisiimme. Lehmäluku on inhimillinen niin lehmien kuin hoitajienkin kannalta. Jokainen hoidokki on oma persoonansa ja sen luonteenpiirteet tunnetaan nimen lisäksi. Joukosta löytyy rauhallisia, leikkisiä, epäluuloisia ja mukavuudenhaluisiakin lehmiä.

(SKS. KRA. EASN. Nimim. Lilli; nainen 31 v.) 
Taija Kaarlenkaski ja Kati Saarinen: Mansikki vai numerosarja?

Tekstissä mainittu "inhimillinen" lehmien määrä viittaa siihen, että se on ihmisen käsitettävissä, jolloin eläimien nimet ja ominaisuudet ovat muistettavissa. Tätä pidetään hyvänä myös lehmien kannalta. Jos lehmiä on yli 50, kaikkien niiden nimien muistaminen alkaa joistakin kirjoittajista tuntua epäuskottavalta. Nimien muistamisen korostamisen voi nähdä eräänlaisena vakuutteluna siitä, että lehmiä hoidetaan suuresta määrästä huolimatta yksilöllisesti (ks. myös Phillips 1994, 125, 130). Eläimien tunnistaminen numeron perusteella vie ajatukset helposti siihen, että niitä käsitellään massana ja niiden yksilölliset piirteet unohdetaan - vaikka näin ei käytännössä välttämättä tapahtuisikaan (Falkengren 2005, 231-232).

\section{NUMERON MERKITYS}

Nykyisin lainsäädäntö edellyttää eläinten merkintätapaa, jossa jokaisella eläimellä on ainutkertainen, korkeintaan 12 numeromerkistä sekä syntymämaan tunnuksesta koostuva EU-tunnus. Tämä tunnus on nähtävissä korvamerkistä, jollainen on kiinnitetty eläimen molempiin korviin. Lisäksi jokaisella lehmällä ja hieholla on enintään nelinumeroinen ns. korvanumero, joka myös näkyy sen toisessa korvamerkissä. Kaikki tuotosseurannassa mukana olevien karjojen eläimet on voitava tunnistaa yksiselitteisesti. Jokaiselle syntyneelle vasikalle kirjataan emä ja isä, ja näiden tunnisteet (emän EU-tunnus, isän kantakirjanumero tai EU-tunnus) merkitään vasikan tietojen yhteyteen. Voikin pohtia, millaisia merkityksiä on sillä, että eläinten tietoja ja tunnistusta käsitellään yhä enenevässä määrin juuri numeromerkin avulla erilaisissa rekistereissä ja asiakirjoissa. Tekniikan lisääntyessä numerotunnisteita käytetään yhä enemmän myös navettojen ja pihattojen sisällä sekä eläintenhoitajien keskinäisissä puheissa. Äkkiseltään voisi ajatella, että numerotunniste vie ihmiset ja hoitajat entistä kauemmaksi eläinten yksilöllisestä kohtelusta. Tästä oltiin huolestuneita myös Ei auta sano nauta -kirjoituskilpailun aineistossa, kuten edellä kävi ilmi. Lähempi tarkastelu kuitenkin osoittaa, että vastaus ei ole yksiselitteinen eikä asiaa voida irrottaa kontekstistaan.

Numerotunniste palvelee eläimen yksilöllistä tunnistamista sekä karjanhoitotyössä että erilaisten rekistereiden ylläpitämisessä. Yhä useammin myös hoitajat käyttävät arjessa rinnakkain eläimen nimeä ja numerotunnistetta. Numerotunnisteen voi ajatella vastaavan ihmisten sosiaaliturvatunnusta, jolla meidät yksilöllisesti tunnistetaan ja joka on virallisissa asioissa nimeämmekin luotettavampi erottamisen peruste. Ihminen on kehitellyt omaan ajattelumaailmaansa sopivan järjestelmän myös eläinten osalta, ja on loogista, että myös eläimillä on oma numeroihin perustuva tunnistusmenetelmä, joka vastaa tarkoitukseltaan ja käytettävyydeltään meidän sosiaaliturvatunnustamme. Nimellä ja korvamerkin tunnistenumerosarjalla onkin erilaiset tehtävät. Ihmisten asenteet sekä tavat hahmottaa ja muistaa asioita vaikuttavat paljon siihen, erotetaanko eläimet toisistaan muistamalla jokaisen yksilön nimi vai sen numerosarja. Esimerkiksi ELKÄ-projektin haastatteluissa eräs mies totesi näin: "minä niistä numeroista muistan, nimi suattaa olla tiukemmassa, kaikki perustuu siihen numeroon" (Mies, tila 1. ELKÄ).

Nimeen ladataan paljon erilaisia tunteita niin ihmisten kuin eläintenkin nimien kohdalla, minkä vuoksi nimet ovat erityisen merkityksellisiä meille ihmisille. Eläinten 
Taija Kaarlenkaski ja Kati Saarinen: Mansikki vai numerosarja?

nimeämiseen käytetään usein samanlaisia menetelmiä kuin ihmistenkin nimeämiseen. Vasikoille annetaan nimi, joka alkaa sinä vuonna käytettävällä alkukirjaimella, mutta muuten nimen voi valita melko vapaasti. Nimeämisen perusteena voi olla esimerkiksi oman lapsen nimellä nimeäminen. Oma lapsi tai muu läheinen ihminen on myös saattanut valita syntyneelle vasikalle nimen. Hoitajalle tai koko perheelle voi muodostua erityinen suhde vasikkaan jo pelkästään nimeen tai nimenantoon liittyvien tekijöiden vuoksi. Erityissuhde muodostuu esimerkiksi silloin, kun lehmä on enemmän lemmikkieläimen asemassa kuin muut karjan eläimet. Suosikkilehmän asemaan nousevat etenkin ne vasikat, joiden syntymäaika on merkityksellinen perheelle tai joille esimerkiksi lapset antavat nimen. Suosikkilehmään liittyviä päätöksiä ei välttämättä tehdä yhtä lailla taloudellisista näkökulmista kuin muiden lehmien kohdalla. Suosikkilehmä saattaa saada vaikkapa enemmän elinaikaa, vaikka sen tuottavuus olisikin jo heikko. Suosikkilehmän elämää myös monesti seurataan tarkemmin, ja se saa enemmän huomiota ja vuorovaikutusta hoitajilta ja perheenjäseniltä kuin muut yksilöt. Haastattelu- ja kyselyaineistoissa nousee esille, että niin sanottujen suosikkilehmien kohdalla sekä lehmän nimi että numerosarja ovat hoitajille tuttuja, ja kaikki enemmän eläimen kanssa tekemisissä olevat tunnistavat yksilön nimeltä. Lisäksi suosikkilehmillä saattaa olla useampia lempi- tai hellittelynimiä: "Ja sitte yks mikä on tietysti lehmilläkin niin ehkä ihmiselläki et tulee lempinimiä” (Mies, tila 2. ELKä).

Tutkimuksissa on pystytty osoittamaan, että nimellä puhuttelulla ja eläimen yksilöllisellä kohtelemisella on vaikutusta lehmän lypsämään maitomäärään. Ne lehmät, joita puhutellaan ääneen nimellä ja joille annetaan yksilöllistä hoitoa ja huomiota, lypsävät enemmän maitoa kuin vähemmän huomiota ja yksilöllistä kohtelua saavat lehmät (Bertenshaw \& Rowlinson 2009, 62, 65, 67). Tutkimuksia, joissa olisi annettu eläimelle huomiota ja hoidettu yksilöllisesti sekä juteltu kuitenkaan käyttämättä mitään erityistä nimeä, ei todennäköisesti ole vielä tehty. Siksi on vaikea erottaa juuri nimen merkityksen osuutta eläimen ja ihmisen välisessä suhteessa ja vuorovaikutuksessa tai nimellä tunnistamisen tai kutsumisen vaikutusta lehmän lypsymäärään ja hyvinvointiin. Tutkimustulokset viittaavat kuitenkin siihen, että eläinten yksilöllisyyden tunnistamisella ja niiden tuotannon määrällä voi olla yhteys.

Hieman yllättäen maidontuottajien ja eläintenhoitajien haastatteluissa (Maitotilan hyvä vointi 2010, ELKÄ 2008, Saarisen pro gradu 2006) nousi esille, että etenkin lehmät tunnistettiin yksilöllisesti parhaiten utareista tai jostain muusta vastaavasta eläimen fysiologisesta ominaisuudesta, ei nimestä tai numerotunnisteesta. Samoin kävi ilmi, että moni myös tunnistaa yksilöllisesti kaikki karjan lehmät, mutta nuoremman karjan yksilöt eivät ole niin selvästi muistissa. Näyttää siltä, että vasta lypsävä lehmä ja ensimmäistä kertaa poikiva hieho pääsevät siihen joukkoon, jossa yksilöllinen tunnistaminen alkaa ihmisen ja eläimen välisessä vuorovaikutuksessa. Poikimisen myötä lehmä ikään kuin ansaitsee paikkansa "työyhteisössä", ja tämän jälkeen sen nimi tulee hoitajille entistä merkittävämmäksi ja se alkaa saada yksilöllisempää kohtelua. Usein myös niin sanotut suosikkilehmät nousevat esille siinä vaiheessa, kun ne alkavat lypsää ja hoitajat ovat niiden kanssa enemmän tekemisissä lypsyn yhteydessä ja tarkkailussa.

Lypsykarjan yksilöiden nimen muistamiseen vaikuttaa usein myös se, että eläin erottuu muista. Sellaisen yksilön, jonka kanssa on enemmän hankaluuksia tai joka sairastelee 
Taija Kaarlenkaski ja Kati Saarinen: Mansikki vai numerosarja?

enemmän kuin muut, nimi ja persoonalliset piirteet saatetaan muistaa muita paremmin. Useissa tässä katsauksessa tarkastelemissamme (MHV, ELKÄ, Saarisen pro gradu) haastatteluissa käy ilmi, että hyvin lypsävä ja hyväkäytöksinen terve lehmä ei välttämättä jää erityisesti mieleen juuri sen takia, että kaikki sujuu vaivattomasti. Seuraavissa haastattelukatkelmissa kommentoidaan sekä lehmien tunnistamista että nimien muistamista:

Tisseistä tuntee 80 lehmää, että sitten näpytellään vaan numero taululle että kuka lehmä on. Tietysti aina kun tulee uus hieho niin pitää miettiä että mikä on korvanumero ja jos on, aikonaan ku armeijaan meni, no joku viisas sano että älä oo joukon viimenen mutta älä oo ensimmäinenkään, sillon ne ei muista sun nimeä, pääset helpommalla. Ja se on sama pätevyys lehmissä elikkä jos et oo mikään tyhmä tai mikä potkii ja etkä oo mikään semmonen tai sanotaan että jos oot siinä keskiporukassa kulkeva niin tätäkin joskus aina miettii että mikä oli korvalätkä tai nimi. Ja minä ehkä enemmänkin muistan korvanumerot, vaimo muistaa nimet.

(Mies, tila 2. ELKÄ.)

Mulla on parempi nimipää

(Nainen, tila 2. ELKÄ).

Maitotilan hyvä vointi -tutkimushankkeen kyselytutkimus tehtiin maidontuottajille, ja kyselyyn vastanneista yli puolet piti tärkeänä, että tunnistaa lehmät nimeltä (Kymäläinen 2011). Tulokset osoittivat myös, että tiloilla, joilla ei lainkaan välitetä lehmien nimistä, on hieman matalampi eläinten hyvinvointi-indeksi. Eri luokkien välillä ei kuitenkaan ollut tilastollisesti merkittävää eroa. Nuoremmat maidontuottajat pitävät eläinten nimellä tunnistamista merkittävämpänä eläimen hyvinvoinnin kannalta kuin vanhemmat vastaajat $(\mathrm{P}=0.0034)$. Siviilisääty osoittautui tilastollisesti erittäin merkitseväksi. Avioliitossa tai avoliitossa tai muun perheen kanssa elävät vastasivat lehmän nimellä tunnistamisen olevan tärkeää tai erittäin tärkeää useammin kuin yksin elävät vastaajat $(\mathrm{P}=0,0006)$. Tämä on mielenkiintoinen tulos, jota olisikin hedelmällistä pohtia syvemmin. Ovatko eläinten nimet enemmän käytössä perheen kanssa elävien karjatilallisten arjessa? Tämä vahvistaisi nimien merkitystä hoitajien ja perheenjäsenten tunnistaessa eläimiä. Käyttääkö yksin elävä mahdollisesti vähemmän eläinten nimiä keskusteluissa tai hoitaessaan eläimiä? Tilastollisesti erittäin merkitsevä ero löytyi myös maanviljelysalan ammatillisen koulutuksen ja ei-ammatillisen koulutuksen käyneiden vastanneiden välillä. Ammatillisen koulutuksen saaneet vastaajat pitivät useammin tärkeänä lehmien tunnistamista nimellä kuin ei-ammatillisen koulutuksen saaneet vastaajat.

Navettatyypillä oli vastauksissa tilastollisesti erittäin merkitsevä ero (Kymäläinen 2011). Pihattonavetoissa lehmien tunnistamista nimillä pidettiin merkityksellisempänä kuin parsinavetoissa $(\mathrm{P}=0,0001)$. Myös lehmien lukumäärällä oli tilastollisesti erittäin merkitsevä ero. Alle 20 lehmän tiloilla eläinten tunnistamisella nimellä oli vähemmän merkitystä kuin suuremmilla tiloilla. 20-40 lehmän tiloilla nimellä tunnistamista pidettiin tärkeänä ja yli 40 lehmän tiloilla todella tärkeänä. Nuorkarjan nimien muistamisen osalta vastaukset olivat samansuuntaisia kuin lehmien nimen muistamisessa. 
Taija Kaarlenkaski ja Kati Saarinen: Mansikki vai numerosarja?

Tilastollisesti erittäin merkittävä ero esiintyi myös tuotantotyyliin liittyen ( $\mathrm{P}=0,0002)$. Luonnonmukaisella kotieläintuotantotilalla nimellä tunnistamista pidettiin useammin tärkeänä kuin tavanomaisella kotieläintuotantotilalla. Tuotosseurantaan kuuluminen vaikutti myös tilastollisesti erittäin merkitsevästi $(\mathrm{P}=0,0001)$. Tuotosseurantaan kuuluvat vastasivat selkeästi useammin eläinten nimellä tunnistamisella olevan heille merkitystä. Sen sijaan alan työkokemuksen pituudella tai esimerkiksi taloustilanteella ei kyselyn mukaan ollut tilastollisesti merkitseviä eroja liittyen eläimen nimellä tunnistamiseen.

Maitotilan hyvä vointi -hankkeen kyselytutkimuksen tulokset ovat jossain märin yllättäviä verrattuna Ei auta sano nauta -kirjoituskilpailun aineistossa esiintyneisiin näkemyksiin. Käsitykset siitä, että eläinmääriltään suuremmilla tiloilla lehmien nimet ja yksilölliset piirteet menettäisivät hoitajille merkityksensä, eivät näytä kyselyn valossa pitävän paikkaansa. Päinvastoin, isommilla pihattotiloilla nimellä tunnistamisella näytti olevan jopa enemmän merkitystä kuin pienillä parsinavettatiloilla. Tätä tulosta voinee ainakin osittain selittää sillä, että pienet tilat ovat usein niitä, jotka ovat lopettelemassa tuotantoaan, minkä vuoksi karjanhoitajat eivät välttämättä ole motivoituneita panostamaan eläinten tarkkailuun ja hyvinvointiin. Toisaalta suurissa yksiköissä toimivat karjanhoitajat voivat vastauksissaan korostaa eläinten nimien merkitystä juuri laajamittaiseen eläintuotantoon kohdistuvien ennakko-oletusten takia. Jos eläinten nimellä tunnistamisen ajatellaan liittyvän sen yksilölliseen kohteluun, tätä varmasti tuodaan mielellään esille.

On tärkeää tutkia myös sitä, kuinka paljon ihminen pystyy aidosti tunnistamaan eri yksilöitä toisistaan ja seuraamaan karjan keskinäisiä vuorovaikutussuhteita ja sukulaisuussuhteita. Ihmisen ja eläimen väliseen suhteeseen vaikuttaisi olevan merkitystä sillä, että ihminen tunnistaa eläimen yksilönä ja muistaa sen nimen tai vastaavasti yksilöllisen numerosarjan. Antropologi ja evoluutiopsykologi Robin Dunbarin (2010) mukaan nimetty Dunbarin luku on teoreettinen kognitiivinen luku sille yksilöiden määrälle, jonka ihminen pystyy tunnistamaan ja lisäksi luontevasti hahmottamaan niiden yksilöiden välisiä sosiaalisia suhteita. Tarkkaa lukua ei ole määritelty, mutta ihmisen kohdalla luvun arvioidaan olevan 150 yksilöä. Muilla kädellislajeilla määrä vaihtelee lajin mukaan korreloiden aivojen neokortexin kokoon. Tätä teoriaa on kritisoitu muun muassa siitä, että se pelkistää ja yksinkertaistaa liikaa. Teoria antaa kuitenkin viitteitä siitä, että yksilöiden tunnistaminen ja erilaisten persoonallisuuksien erottaminen on rajallista niin ihmisten kuin eläintenkin kohdalla, ja tämä on hyvä huomioida myös eläinten hoitoa ja karjakokoon liittyviä suunnitelmia tehtäessä.

\section{LOPUKSI}

Nimi tekee niin ihmisestä kuin eläimestäkin yksilön. Tarkastelemamme aineistot osoittavat, että nautojen nimillä on ollut ja on edelleen karjanhoitajille merkitystä: tietyt yksilöt voidaan muistaa nimeltä vielä vuosikymmenien jälkeen. Nimien muistaminen ja eläinten puhutteleminen nimellä näyttää myös säilyttävän merkityksensä, vaikka karjakoot ovat viime vuosina kasvaneet voimakkaasti. Tässä mielessä naudat eroavat 
Taija Kaarlenkaski ja Kati Saarinen: Mansikki vai numerosarja?

muista tuotantoeläimistä kuten sioista, joille erisnimiä ei tietääksemme tavallisesti anneta. Toki sikatiloilla eläinmäärät ovat vielä huomattavasti suurempia kuin lypsykarjatiloilla, joten jo muistin kapasiteetti asettaa rajoituksia eläinyksilöiden tunnistamiselle. Suuret eläinyksiköt aiheuttavatkin haasteita juuri yksilölliselle kohtelulle ja yksilöiden tunnistamiselle, mikäli eläinten hoito on kokonaan yhden tai kahden ihmisen vastuulla. Toisaalta nautojen nimeäminen ja yksilöiminen on ristiriitaista, sillä tuotantoeläiminä suosikkilehmätkin päätyvät lopulta teurastamolle. Tämä ambivalenssi on karjanhoidossa muodostuvien ihmisten ja eläinten suhteiden keskeinen piirre, joka ilmenee monilla tasoilla, myös eläinten nimeämisessä (Holloway 2001; Saarinen 2007; Wilkie 2010; Kaarlenkaski 2012).

Käyttämissämme aineistoissa lehmien nimet eivät olleet keskeisimpiä kysyttyjä asioita, mutta ne nousivat kuitenkin esille sekä kirjoituskilpailutekseissä että karjanhoitajien puheissa ja kyselyvastauksissa. Näistä aineistoista tekemämme huomiot herättävät lisäkysymyksiä. Olisi mielenkiintoista tutkia enemmän muun muassa sitä, kuka valitsee eläimille nimet. Jos esimerkiksi perhetilalla maanviljelijäpuolisoista nainen valitsee useammin eläinten nimet, vaikuttaako tämä siihen, että näillä tiloilla miehet eivät välttämättä muista tai tunnista eläintä yhtä hyvin nimeltä vaan esimerkiksi korvamerkin numeron tai jonkin ulkoisen ominaisuuden perusteella? Entä missä tilanteissa lehmistä käytetään nimiä, missä taas numerotunnisteita?

Joka tapauksessa nimien antamisessa vaikuttaa olevan paljon erilaisia käytäntöjä. Toiset antavat naudoille ihmisten nimiä ja voivat tehdä niistä jopa lapsiensa kaimoja, kun taas jotkut eivät pidä ihmisten nimien antamista sopivana. Lajirajojen ylittäminen yhteisillä nimillä on siis joissakin tapauksissa mahdollista. On kuitenkin muistettava, että eläinten nimeämisessä ja nimen käyttämisessä valta on ihmisellä (ks. myös Borkfelt 2011, 117-118). On karjanhoitajien vallassa, mistä yksilöistä tulee virallisen nimen lisäksi lempinimiäkin saavia suosikkeja. Tämä korostuu siinä, että nykytiloilla eläinten nimet tulevat todella merkittäviksi vasta siinä vaiheessa, kun hieho poikii ja liittyy taloudellisesti arvokkaiden maidontuottajien joukkoon. Nuoren karjan ja lihaksi kasvatettavien sonnien nimiä ei muisteta yhtä hyvin. Voi pohtia myös sitä, onko nimen antaminen välttämättä tae yksilöllisestä kohtelusta ja eläimen hyvinvoinnista. Jos eläimen perustarpeet ovat kunnossa ja sitä kohdellaan hyvin, sille itselleen ei erisnimellä todennäköisesti ole merkitystä.

Lehmien nimiin liittyviä mielikuvia hyödynnetään kuitenkin myös maitotuotteiden markkinoinnissa. Valion syksyllä 2012 lanseeraamassa mainoskampanjassa korostettiin, että yhtiön tuotantotiloilla lehmillä on nimet ja niitä kohdellaan ikään kuin perheenjäseninä. Samoin peliyhtiö Rovio on kertonut käyttävänsä maitoa sisältävien välipalajuomiensa markkinoinnissa lehmien nimiä. Venäjälle ja Kiinaan suunnattujen tuotteiden mainonnassa on väitetty Rovion tuntevan nimeltä Suonenjoen kaikki 3000 lehmää. Markkinointijohtaja Peter Vesterbackan mukaan "[1]ehmien nimellä on merkitystä markkinointiviestinnässä, koska esimerkiksi Kiinassa maidon puhtaudesta ei voi olla varma”. (Sipilä 2013.) Lehmien nimien tietäminen esitetään siis takuuna maidon alkuperän tuntemisesta ja sen puhtaudesta. Tarkastelumme osoittaa, että tuotantoeläinten nimillä on merkitystä niin karjanhoitajille kuin kuluttajillekin, ja niitä tulisi tarkastella yhtenä osana ihmisten eläinsuhteita. 
Taija Kaarlenkaski ja Kati Saarinen: Mansikki vai numerosarja?

\section{VIITTEET}

1 Welfare Quality oli vuosina 2004-2009 toteutettu laaja EU:n rahoittama tutkimusprojekti, jossa tuotettiin eurooppalaiset mittaristot sikojen, nautojen ja siipikarjan hyvinvoinnin arviointiin tilatasolla. Welfare quality -menetelmällä arvioidaan eläinten käyttäytymistä, sosiaalisia kontakteja ja ulkoisia hyvinvoinnin merkkejä, kuten karvapeitteen ja ihon kuntoa. Arviointijärjestelmään sisältyy myös eläimen positiivisten tunteiden arviointia. Menetelmä on vielä kehitysvaiheessa ja sen toimivuutta testataan edelleen muiden tutkimushankkeiden yhteydessä. (Eläinten hyvinvointi Suomessa 2012, 17, 33, 53).

2 Myös monissa muissa kielissä nautaa tarkoittava sana viittaa alkuperältään omaisuuteen (Rifkin 1993, 28).

3 Viitteissä Ei auta sano nauta (EASN) -kirjoituskilpailun aineistoon käytetään samaa menettelyä kuin Kaarlenkasken väitöskirjassa, eli tarkkoja arkistonumeroita ei julkaista kirjoittajien anonyymiyden varmistamiseksi. Ks. Kaarlenkaski 2012, 121.

4 Katharina Leibringin mukaan Ruotsissa perinteisiä lehmännimiä ei enää käytetä, vaan eläimet erotetaan toisistaan kantakirjanumeron perusteella. Jos erisnimiä käytetään, lehmä perii emänsä nimen, jonka perään lisätään järjestysnumero. Näin nimistä on tullut lähinnä "sukunimiä". Leibring yhdistää tämän käytännön tilakokojen ja eläinmäärien kasvuun. (Leibring 2000, 426-427, 448; ks. myös Falkengren 2005, 230-232.)

\section{TUTKIMUSAINEISTOT}

Suomalaisen Kirjallisuuden Seura (SKS), Kansanrunousarkisto (KRA). Ei auta sano nauta - kirjoituskilpailu lehmästä (EASN), 2004.

Juski: Kesän ensimmäinen päivä. Mies 38 vuotta. 8 sivua. Kymenlaakso.

Lilli: Ei auta sano nauta. Nainen 31 vuotta. 5 sivua. Pohjois-Karjala.

Meni: Vanhan navettatontun mietteitä. Nainen 35 vuotta. 4 sivua. Kymenlaakso.

Pieni Paimenpoika: Ne meidän lehmät. Mies 69 vuotta. 9 sivua. Pohjois-Karjala.

Uneksija: Elämäni eläimet. Nainen 38 vuotta. 11 sivua. Etelä-Pohjanmaa.

Eläinlähtöinen käsittely, MTT kotieläintuotannon tutkimus, 2008.

Mies, Tila 1. litteroitu teemahaastattelu. Työkokemusta alalla vähintään 10 vuotta. Mies, Tila 2, litteroitu teemahaastattelu. Työkokemusta alalla vähintään 10 vuotta.

Nainen, Tila 2, litteroitu teemahaastattelu. Työkokemusta alalla vähintään 10 vuotta.

Maitotilan hyvä vointi -hankkeen kyselytutkimuksen aineisto kerätty keväällä 2010. Alueena koko Suomi. (Ks. Kymäläinen 2011). 
Taija Kaarlenkaski ja Kati Saarinen: Mansikki vai numerosarja?

\section{KirjallisuUs}

BERTENSHAW, CATHARINE \& ROWLINSON, PETER 2009: Exploring Stock Managers' Perceptions of the Human-Animal Relationship on Dairy Farms and an Association with Milk Production. - Anthrozoös 22(1).

BORKFELT, SUNE 2011: What's in a Name? - Consequences of Naming Non-Human Animals. - Animals 1(1).

DUNBAR, ROBIN I. M. 2010: How many friends does one person need? Dunbar's number and other evolutionary quirks. London: Faber and Faber.

ELLIS, COLTER \& IRVINE, LESLIE 2010: Reproducing Dominion: Emotional Apprenticeship in the 4-H Youth Livestock Program. - Society and Animals 18(1).

ELÄINTEN HYVINVOINTI SUOMESSA 2012: Kansallinen eläinten hyvinvointiraportti. Helsinki: Maa- ja metsätalousministeriö, Helsingin yliopisto ja Evira [online]. < http://elaintenhyvinvointikeskus.edublogs.org/files/2012/02/EHV_raportti_valmis_16.5.2012-27hf7uk.pdf > [21.2.2013.]

FALKENGREN, JUTTA 2005: Djurens skepnader: Närhet och distans i diskurs och livsvärld. Lund: Lund University.

HOLLOWAY, LEWIS 2001: Pets and Protein: Placing Domestic Livestock on HobbyFarms in England and Wales. - Journal of Rural Studies 17.

HÄKKINEN, KAISA 2002: Eläin suomen kielessä. - Henni Ilomäki \& Outi Lauhakangas (toim.), Eläin ihmisen mielenmaisemassa. Helsinki: SKS.

KAARLENKASKI, TAIJA 2012: Kertomuksia lehmästä. Tutkimus ibmisen ja kotieläimen kulttuurisen subteen rakentumisesta. Joensuu: Suomen Kansantietouden Tutkijain Seura.

KALSKE, MARJA 2005: Suomessa syntyneiden hevosten nimistö. Turku: Turun yliopisto.

KYMÄLÄINEN HANNA-RIITTA (toim.) 2011: Maitotilan hyvä vointi -hankkeen loppuraportti. Maataloustieteiden laitos, julkaisuja 9. Helsinki: Helsingin yliopisto, maataloustieteiden laitos [online]. < https://helda.helsinki.fi/bitstream/handle $/ 10138 / 29081 / \mathrm{MHV}$ loppuraportti100112.pdf ?sequence $=4>$ [18.2.2013.]

LEIBRING, KATHARINA 2000: Sommargàs och Stjärnberg. Studier i svenska nötkreatursnamn. Uppsala: Kungl. Gustav Adolfs Akademien för svensk folkkultur.

MELSON, GAIL F. 2001: Why the Wild Things Are. Animals in the Lives of Children. Cambridge: Harvard University Press.

OJANSUU, HEIKKI 1912: Kotieläintemme suomenkielinen nimistö etupäässä maanviljelijäin tarpeeksi. Helsinki: Kirjapaino-osakeyhtiö Sana.

PHILLIPS, MARY T. 1994: Proper Names and the Social Construction of Biography: The Negative Case of Laboratory Animals. - Qualitative Sociology 17(2).

RIFKIN, JEREMY 1993: Beyond Beef. The Rise and Fall of the Cattle Culture. New York: Plume.

SAARINEN, KATI 2007: "Onkohan tää homma näille lehmille miten tuskallista?" Maidontuottajien ja asiantuntijoiden mä̈ritelmiä eläinten hyvinvoinnista ja tiedon luotettavuudesta. Julkaisematon yhteiskuntapolitiikan pro gradu -tutkielma. Joensuu: Joensuun yliopisto, yhteiskuntapolitiikan laitos. 
Taija Kaarlenkaski ja Kati Saarinen: Mansikki vai numerosarja?

SAARINEN, KATI \& RAUSSI, SATU 2009: Karjanhoitajan sukupuoli ja naudan ja hoitajan välinen suhde [online]. < http://www.proagria.fi/ek/uutisia/karjanhoitaja_nauta.html > [18.2.2013.]

SIPILÄ, ANNA-MARI 2013: Rovio kehuu tietävänsä 3000 lehmän nimen. - Helsingin Sanomat, verkkolehti 12.2.2013 [online]. < http://www.hs.fi/msn/talous/Rovio +kehuu+tiet\%C3\%A4v\%C3\%A4ns\%C3\%A4+3000+lehm\%C3\%A4n+nimen/ a1360637427142 > [12.2.2013.]

TERVO, MIRJA 2004: Lehmä. Jyväskylä: Atena.

VATANEN, OSMO 1997: Ystävä, Hyvä ja Äpyli - nämäkin lehmännimiä. Vantaa: Suomen kotieläinjalostusosuuskunta.

VILKUNA, KUSTAA 1976: Lehmän kotiutuminen perheeseen, naudan asettuminen yhteiskuntaan. - Virittäjä 80.

WILKIE, RHODA 2010: Livestock/Deadstock. Working with Farm Animals from Birth to Slaughter. Philadelphia: Temple University Press.

Filosofian tohtori Taija Kaarlenkaski on joensuulainen perinteentutkija. Yhteiskuntatieteiden maisteri Kati Saarinen tekee ympäristöpolitiikan väitöstutkimusta Itä-Suomen yliopistossa. 